OPEN ACCESS

Edited by:

Margaret Grogan,

Chapman University, United States

Reviewed by:

Tamara Lipke,

SUNY Oswego, United States Kristina Astrid Hesbol,

University of Denver, United States

*Correspondence:

Rodolfo Rincones rrincones@utep.edu

Specialty section:

This article was submitted to Leadership in Education, a section of the journal Frontiers in Education

Received: 16 October 2020 Accepted: 15 December 2020

Published: 14 January 2021

Citation:

Rincones R, Peña I and Canaba KC (2021) A Call for Rethinking Schooling and Leadership in the Time of COVID-19. Front. Educ. 5:618075.

doi: 10.3389/feduc.2020.618075

\section{A Call for Rethinking Schooling and Leadership in the Time of COVID-19}

\author{
Rodolfo Rincones ${ }^{1 *}$, Isela Peña ${ }^{2}$ and Karina Chantal Canaba ${ }^{1}$ \\ ${ }^{1}$ Educational Leadership and Foundations, College of Education, The University of Texas at El Paso, El Paso, TX, \\ United States, ${ }^{2}$ Department of Education, College of Education and Professional Studies, Sul Ross State University, Alpine, \\ TX, United States
}

COVID-19 forced a sudden closure of schools, prompting a hasty and unplanned reaction of educators to deliver educational content. Inspired by Ivan Illich's book Deschooling Society, where he argues for the delivery of educational content by utilizing technology and forging intentional partnerships with parents and communities to assist in the delivery of educational content, we reflect on how these ideas impact school leadership and preparation of school leaders. This "forced" deschooling has offered educators an opportunity to rethink the true purpose of education, and redesign flexible, creative and innovative instructional strategies for delivering educational materials and knowledge, as well as rethinking the role of and preparation of educational leaders. While we do not offer quick solutions, our intent is to revisit Illich's Deschooling Society as a means to examine and question our school system introspectively and collectively.

Keywords: COVID-19, deschooling, principal preparation, Ivan Illich, leadership

\section{INTRODUCTION}

As we know by now, COVID-19 has caused tremendous human trauma by killing hundreds of thousands, sickening tens of millions, and creating economic havoc across the world. In education, schools and universities unexpectedly closed, creating disruptions in the educational activities of millions of students, teachers, and other staff. It is tough to predict when schools will reopen and how they will continue to provide educational activities to students. The most hopeful predictions anticipate reopening schools in spring of 2021 but continue to rely heavily on technology to deliver academic instruction. This new world context finds educational leaders left struggling to determine how to return to the "old days" or adapt to the "new normal" and forced to make decisions amid unprecedented uncertainty.

The sudden closure of schools prompted a hasty and unplanned reaction of educators to deliver educational content. In this essay, inspired by Ivan Illich's book Deschooling Society, we argue that the closing of the schools has offered educators an opportunity to rethink education and schools' real purpose, and redesign flexible, creative, and innovative instructional strategies for delivering platforms for learning. While Illich did not specifically address principal preparation and leadership, within the deschooling structure he proposed, he argues the role of the school leader would transform to what he coined a network administrator or over time become obsolete (Illich, 1972). In the role of network administrators, school leaders would serve as a concierge of a liberated learning system. We think that revisiting Illich's proposals provides educational leaders ways to visualize a new delivery of educational content by utilizing technology and forging intentional partnerships with parents and other adults to assist in delivering educational content and supervision of the educational processes. And ultimately, loosen, if not liberate, students of suffocating school environments that we have managed to create. 
To make our argument, we proceed first to provide a brief overview of the pandemic's impact in education, creating a chaotic present and an uncertain future filled with unknowns, and how educational leaders have been trying to cope with these uncertainties. Then, we review the controversial proposals made by Illich in his 1970 book, including the use of learning channels, balancing the power between teacher and students, and creating school leaders who serve as network administrators. We then present some of the counterarguments to his request, including his own critique. Then, we go back to some of the proposals made by Illich and repurpose them in light of the "forced" deschooling of society caused by the pandemic. In the third and final section of the paper, we discuss, informed by Illich's proposals, the implications for preparing educational leaders to lead under the "new" set of circumstances created by the pandemic. We aim to incite conversations around preparing educational leaders in light of the pandemic or perhaps other crises. We must strive to reframe our view of an educational leader's role in a context filled with uncertainties.

\section{IMPACT OF COVID-19 ON EDUCATION}

As of September 1, 2020, 778,000,000 or 44 percent of all learners were impacted by full or partial school closures because of COVID-19 (United Nations Educational, Scientific, and Cultural Organization, 2020). If we take a look at what happened prior to this date, we see that by the end of March 2020, " $90 \%$ of the world's student population was out of class" (Mokhtar and Gross, 2020). As a result of shelter in place orders, schools at all levels quickly shuttered in an attempt to help reduce the spread of COVID-19 (Mokhtar and Gross, 2020). Lockdowns in the United States began in mid-March and continued through early April 2020 through a patchwork of stay at home orders that varied by state with varying degrees of consistency (Ravani, 2020). In Spring 2020, at the height of school closure mitigation efforts in the United States, $\sim 55.1$ million students and 124,000 public and private schools were impacted (Education Week, 2020a). There has been a push to reopen schools for face-to-face instruction to mitigate adverse impacts on students' health and well-being due to not being in school to include their social and emotional growth, safe learning environments, and nutritional needs. Additionally, many mentioned the needs of low-income and minority children who lost access to necessary resources such as special education services, counseling, and after-school programs due to shelter in place orders (Center for Disease Control Prevention, 2020).

The question looming for educators became how to continue with educational activities that did not negatively impact public health and find creative avenues for educational delivery (American Federation of Teachers, 2020; Reimers and Schleicher, 2020). Teachers across the United States argued that reopening could happen, so long as it is safe and responsible (American Federation of Teachers, 2020). Much like shelter in place orders, decisions have varied with different plans and proposals. Officials' responses have been mostly contextual and ambiguous, with current conditions and spread dictating the decisions as to how best approach teaching in these circumstances. Decisions on reopening schools have varied by country with different mitigation measures implemented, though few countries have opted for full reopening (Reimers and Schleicher, 2020). Absent a national policy in the United States, individual states implemented different school reopening strategies (Education Week, 2020b), which had to be continuously revisited as the COVID-19 number of infections fluctuated in their regional communities.

The concern with returning to face-to-face instruction is related to children and the asymptomatic spread of COVID19 to adults (Boast et al., 2020). Consensus on findings with children and COVID-19 has been challenging because most data available has focused on adults and those who were symptomatic and testing and tracing (Leeb et al., 2020) with more information needed to understand what role children play in infection and transmission of COVID-19. Thus, many are hesitant to return to full face-to-face instruction. Instead, schools in the United States have implemented mitigation strategies like staggered schedules or allowing specific ages of children to return to the classroom with physical distancing in place along with online/distance learning to aid learning (Reimers and Schleicher, 2020; Education Week, 2020b).

\section{DESCHOOLING SOCIETY}

Illich (1926-2002) was a philosopher of his time. Even though his ideas went into oblivion for some time, the current context of societal and educational issues offer an invitation to revise and rethink his views. He wrote about issues that were exceedingly pressing around the time of this publication when there were political, social, and cultural upheavals and transformations worldwide. He directed his thinking and criticism toward issues he considered the "sacred cows" in society: health, transportation, and education. However, the concerns that he paid attention to have been present in most modern society, particularly in advanced industrial societies.

Illich criticized the institutions that become counterproductive in our lives; that is, institutions that are supposed to produce positive effects but end up producing effects contrary to what was expected (Illich, 1972). He indicates that there are two forms of social institutionalization: heteronomous and autonomous. The former refers to forms of regulations and decisions, where almost everything is defined for us. Illich thinks that schools have become heteronomous institutions, producing effects contrary to what they are supposed to achieve: freedom, creativity, happiness, and desire to learn when we need it and when we want to learn. Today, everything about education is regulated by the state, and certificates and diplomas have increased weight in a meritocratic society. People are valued for their degrees and where these degrees are from, linked to the rituals that allow people to 
obtain such diplomas. Schools have become institutions of social control. All of the educational processes are dependent on professionals or experts who prevent even further making educational processes more autonomous. Illich suggests that heteronomous institutions are antagonist to human nature that must be dismantled.

Illich's published Deschooling Society in 1971 and generated waves of commentary and criticisms. In this book, he describes how education and schools contribute to the social realities embedded in industrialized societies and allow the reproduction and survival of them. The ideas put forward in this book received enormous attention and criticism. Even Illich grew dissatisfied with some of the ideas he advanced in the controversial book. He expressed several years later that although his original work might have helped people to reflect about schools and the collateral effects caused by this institution, he was "barking at the wrong tree" (Illich, 1995). Illich indicated that he argued for the disestablishment of educational institutions and not for the complete elimination of schools. He was more concerned about the institutionalized educational system's genesis than about pedagogical issues and the social imaginary of what it meant to be educated than proposing alternatives to the institutionalized educational system.

Illich received many criticisms about his ideas. Illich had arguments of those who defended educational institutions and those arguing against schools (Zaldivar, 2011). For most educators, mostly liberal and progressive educators, Illich was a difficult pill to swallow. These educators thought they were part of the solution, but their ideas were notably not radical enough in Illich's view (Zaldivar, 2011).

Gintis (1972) made one of the most significant critiques, not of Illich's ideas but about his methodology employed to support his arguments. For Gintis, "Illich does more than merely criticize; he conceptualizes constructive technological alternatives to repressive education" $(1972,71)$. However, for Gintis, Illich's analysis is "simplistic" in the sense that his perspective was not holistic enough, choosing, instead, to analyze a significant but a small aspect (education system) in a very complex web of capitalist and social structures. Hence, for Gintis, Illich's program “... is a diversion from the immensely complex and demanding political, organizational, intellectual, and personal demands of revolutionary reconstruction in the coming decades" $(1972,71)$.

Fast forward to the second decade of the 21st century, and the issues that generated critiques by Illich and other progressive analysts are still very much present today. The crisis caused by COVID-19 pandemic has aggravated school conditions and has reanimated the need to engage in a critical discussion around Illich's proposals for rethinking schooling, specifically liberating learning by moving away from compulsory education and heavily prescribed curricula and by extension, school leadership. While we do not agree with Illich's thinking that the role of the leader would become obsolete, we use his deschooling ideas as a catalyst to reimagine educational leadership and principal preparation.

\section{EDUCATIONAL LEADERSHIP IN LIGHT OF THE "FORCED" DESCHOOLING OF SOCIETY}

The "forced" deschooling experienced across the nation due to the COVID-19 pandemic has presented numerous teaching and learning challenges. COVID-19 has necessitated quick adjustments by the student, the teacher, the family, and the school leader. More importantly, COVID-19 has unintentionally provided an opportunity to rethink how we prepare educational leaders for this new context. Intertwined with school leadership is the actual delivery of education. Before delving into a discussion of how educational leadership preparation may need to evolve, we set the stage by briefly looking at some of the pedagogical adjustments we have seen and how they reflect Illich's thinking in Deschooling Society.

In the wake of COVID-19, schools closed their physical buildings and moved learning from a face-to-face format to an online delivery system without any time to plan and prepare. As the school year came to a close, many expected that schools would begin the 2020-2021 school year in the traditional faceto-face format. Yet, what we saw was school starting the new year utilizing online learning and, in some cases, a combination of face-to-face instruction and online learning. Many behaviors frowned upon in a pre-COVID world, such as cell phones or other technologies, were turned into necessary instructional tools by COVID-19. COVID-19 has left schools without any other choice; the technology is now the lifeline of schools. Yet, anecdotally and from some early research (Narvaez Brelsford et al., 2020), we know and have witnessed numerous issues with online learning, including but not limited to: a lack of training in the use of these technological modalities for teachers, students, and families alike; the absence of a systematic implementation and learning plan; issues with access to technological equipment; no internet access; poor connectivity; problems with the amount of time students are being asked to sit in front of a computer; and questions surrounding grading, testing and accountability.

Embedded in these experiences and issues are Illich's critical criticisms of schooling. Illich puts forth the idea that there are four distinct channels or learning exchanges that could contain all the resources needed for learning, "which are [t]hings, models, peers, and elders" (Illich, 1972, p. 76). These resources are everywhere, but Illich argues that school systems have monopolized the things used to learn, the curriculum, and have repackaged all the learning tools, making them accessible only by the teacher or by students at the discretion of the teacher (Illich, 1972). The sole authority for learning and to determine if learning is occurring rests in the teacher's hands. School leaders play a similar role in restricting access to learning tools by limiting or controlling access to areas in a school building designated for learning. Suppose we subscribe to Illich's assertion that educational learning opportunities and artifacts are found everywhere, at least in our current context. In that case, we need to begin reimagining what this means in an online learning environment. In many ways, online learning has disrupted the power dynamic between teacher and student, and the role teacher 
plays as the guardian of learning. We need to reconfigure the learning relationship between the teacher and the student to integrate the family and community in a meaningful way.

Illich also speaks to networks of learning and learning that is anchored in solving a problem of the student's choosing (1972, 19). To limit the teacher's control of the learning, Illich suggests organizing learning networks around books rather than teachercreated themes. There should also be flexibility around when these networks meet to work and learn instead of a traditional rigid schedule of learning. In this respect, Illich describes what we today would term project or problem based learning (Ravitz, 2010). Project-Based Learning (PBL) is a very much studentcentered pedagogy, in contrast to face-to-face teaching (Mitchell et al., 2005; Buck Institute for Education, 2012). Some of the common characteristics of a traditional classroom are the following: the teacher designs learning in a large classroom setting; teacher-centered and teacher-led learning; assessments and evaluations; and the teachers tell the students what they need to know. In an online setting, these traditional components of the classroom are challenging to replicate. Illich's notion of learning networks, combined with Project-Based Learning provides us with an opportunity to think about how to improve online learning delivery.

Illich also argues that "[i]n school we are taught that valuable learning is the result of attendance; that the value of learning increases with the amount of input; and, finally, that this value can be measured and documented by grades and certificates" (1972, 39). This form of schooling diminishes the creativity of students and may ultimately lead to alienation. Illich offers that "[m] ost learning is not the result of instruction. It is rather the result of unhampered participation in a meaningful setting" $(1972,39)$. When we think about the challenges presented around online learning and the complaints around how many hours students sit in front of a computer, if we consider what Illich is arguing, we can reimagine/rethink how learning is delivered. COVID-19 presents us with an opportunity to reimagine the online "meaningful setting" for student learning to occur.

In Illich's original criticism of the education system, the administrator's role would, over time, become obsolete or, at best, be redefined $(1972,97)$. As we think about the possibilities for schools in this pandemic, we are not suggesting the removal of school leaders. Instead, we see the role of leaders as more important than ever. COVID-19 presents an opportunity to rethink and reimagine the role educational leaders play and how they are trained. Illich redefines the administrator role to what he calls a network administrator (Illich, 1972). This network administrator becomes a broker between what the student desires to learn and source of that knowledge, recognizing that the source may exist outside of the school building.

Illich's Deschooling Society centers around teaching, learning, and curriculum. In school leadership, instructional leaders are charged with leading the teaching to improve student learning outcomes (Ovando and Cavazos, 2004; Reardon, 2011). For instructional leaders, the core of their work is to ensure all students' academic achievement (Ovando and Cavazos, 2004). School leaders are a critical architect of a school's culture (Beatty, 2007). For teachers to engage in collaborative inquiry and work around teaching and learning, school leaders need to ensure that the culture they create provides teachers with social and emotional safety to "encourage creativity, bold selfcritique, rigorous practices and genuine collaborative inquiry" (Beatty, 2007, p. 48). If these conditions are not present, school leaders need to re-culture the school to establish these conditions. For teachers, "[t]he professional domain of the classroom is emotionally sensitive territory. Understandably, sensitivity to these emotion (sic) matters is foundational to effective instructionally focused leadership" (Beatty, 2007, p. 50). One can only imagine that this emotionally sensitive territory has only intensified as the traditional classroom has ceased to exist, leaving teachers to feel more vulnerable than ever before about their teaching and their role in education. COVID-19, whether we want to or not, forces us to rethink schooling and particularly, how instruction is delivered and to redefine the classroom. School leaders need to learn how to create these environments while simultaneously dealing with their own emotions.

We believe that at its core, leadership is about human relationships and that by this very nature, it is impossible to excise the emotional component from human relationships, and thus from leadership as well. Paradoxically, infusing an honest emotional piece into leadership is "luxury that most leaders ... simply cannot afford, not even with themselves" (Beatty, 2007 , p. 57). We see time and time again a desire to display leadership, even in the middle of a crisis, as calm and collected. School leaders are "keenly aware of the professional imperative to remain emotionally hidden, calm, and rational at all times" (Beatty, 2007, p. 57). The uprooting of our educational system and the "forced" deschooling that has occurred coupled with the COVID-19 pandemic has created a highly emotional experience. School leaders do not enjoy an exemption from the emotions that arise in the context this unseen crisis has created. We also know that moments of crisis can "exacerbate ... fear of failure, fear of change or stagnation, fear of being criticized, fear of being dismissed, and fear of losing one's professional identity" for school leaders (Berkovich and Ori, 2015, p. 137). Yet, for school leaders to display a level of professionalism expected of them, they need to exhibit "emotional silence" (Beatty, 2007, p. 51). This perspective is counterproductive to school leaders' expectations to create environments and cultures where teachers feel safe to engage in creative and collaborative inquiry around teaching and learning. In preparing future school leaders, we need to create opportunities and safe spaces to explore emotion in leadership. We need to approach leadership with a lens that captures the whole individual and incorporates the humanity the role demands. One way which we can humanize leadership is by leaders embracing their vulnerability to create cultures where honest conversations can take place and constructive feedback can be given and received (Brown, 2012).

In the context of leadership preparation, if we subscribe to Illich's call to revolutionize education we would expand leadership preparation programs beyond the current national standards to incorporate the following elements: dialogical reflexivity; examination of national and local sociopolitical contexts; an interrogation of power, particularly what it means, how we exercise it and how it is exercised on us; and, historical analysis of inequities that permeate education and continue to exist today. We believe these changes would enhance leadership 
preparation programs and result in leaders better suited to address the needs of our school communities. While we recognize that these types of changes would be incremental and will take time to implement, and perhaps utopian, this is something that leadership programs should strive to achieve.

In our current research literature on school leadership and leadership preparation, we have numerous examples aligned to Illich's proposals. For example, the work of Marshall and Oliva (2006) on leadership for social justice urges us to teach educators revolutionary strategies "for rethinking and taking leadership for school practices to better meet diverse students' needs" $(2006,4)$. Culturally responsive leadership which calls for the liberation of marginalized communities from the oppressive systems and actors, and a validation for cultural history, values and knowledge provides another entry point to this work (Khalifa et al., 2016). Galloway and Ishimaru (2015) propose 10 high leverage leadership practices that help school leaders address issues of ethnic, racial, and economic disparities in our schools. These practices also focus leadership preparation programs on questions of equity across all facets of schooling, including the context of the school community, teaching and learning, resource allocation, and leadership practices.

\section{REFERENCES}

American Federation of Teachers. (2020). A Plan to Safely Reopen America's Schools and Communities. Available online at: https:/www.aft.org/sites/default/files/ covid19_reopen-america-schools.pdf (accessed October 1, 2020).

Beatty, B. (2007). Feeling the future of school leadership: learning to lead with the emotions in mind. Lead. Manag. 13, 44-65.

Berkovich, I., and Ori, E. (2015). Educational leaders and emotions. Rev. Educ. Res. 85, 129-67. doi: 10.3102/0034654314550046

Boast, A., Munro, A., and Goldstein, H. (2020). An Evidence Summary of Pediatric COVID-19 Literature. Don't Forget the Bubbles. doi: 10.31440/DFTB.24063

Brown, B. (2012). Daring Greatly: How the Courage to Be Vulnerable Transforms the Way We Live, Love, Parent, and Lead. New York, NY: Avery Penguin Random House.

Buck Institute for Education. (2012). What is $P B L$ ? Available online at: https:// www.pblworks.org/what-is-pbl (accessed June 5, 2012).

Center for Disease Control and Prevention. (2020). Operating Schools During COVID-19: CDC's Considerations. Available online at: https://www.cdc.gov/ coronavirus/2019-ncov/community/schools-childcare/schools.html?CDC_ AA_refVal=https\%3A\%2F\%2F (accessed October 1, 2020).

Education Week. (2020a). Map: Coronavirus and School Closures in 2019-2020. Available online at: https://www.edweek.org/leadership/map-coronavirusand-school-closures-in-2019-2020/2020/03 (accessed December 12, 2020).

Education Week. (2020b). Coronavirus and Learning: What's Happening in Each State. Available online at: https://www.edweek.org/policy-politics/coronavirusand-learning-whats-happening-in-each-state/2020/04. (accessed December 12, 2020).

Galloway, M. K., and Ishimaru, A. M. (2015). Radical recentering: equity in educational leadership standards. Educ. Admin. Q. 51, 372-408. doi: $10.1177 / 0013161 X 15590658$

Gintis, H. (1972). Towards a political economy of education: a radical critique of ivan illich's deschooling society. Harvard Educ. Rev. 42, 70-96. doi: 10.17763/haer.42.1.h2m4644728146775

Illich, I. (1972). Deschooling Society. New York, NY: Harper \& Row.

Illich, I. (1995). "Foreword," in Deschooling Our Lives, ed M. Hern (Gabriola Island, BC: New Society Publishers).

Khalifa, M. A., Gooden, M. A., and Davis, J. E. (2016). Culturally responsive school leadership: a synthesis of the literature. Rev. Educ. Res. 86, 1272-1311. doi: $10.3102 / 0034654316630383$
Hopefully, with this essay, we have provoked conversations around schooling, and the opportunities COVID-19 is presenting the educational school system. In particular, we hope that we begin to think about alternative ways of delivering instruction and preparing future school leaders to lead in environments that may be continuously afflicted with uncertainties.

\section{DATA AVAILABILITY STATEMENT}

The original contributions presented in the study are included in the article/supplementary material, further inquiries can be directed to the corresponding author/s.

\section{AUTHOR CONTRIBUTIONS}

RR contributed to conceptual design of article writing of introduction and one section of the paper, and revisions. IP assisted in conceptual design, writing, and revisions. KC wrote one of the sections, final revisions, and editing. All authors contributed to the article and approved the submitted version.

Leeb, R., Price, S., Sliwa, S., Kimball, A., Szucs, L., Caruso, E., et al. (2020). COVID19 Trends among school-aged children- United States. MMWR Morb. Mortal Wkly. Rep. 69, 1410-1415. doi: 10.15585/mmwr.mm6939e2

Marshall, C., and Oliva, M. (2006). "Building the capacities of social justice leaders," in Leadership for Social Justice: Making Revolutions in Education, eds C. Marshall and M. Oliva (Boston, MA: Pearson), 1-15.

Mitchell, K., Shkolnik, J., Song, M., Uekawa, K., Murphy, R., and Garet, M. (2005). Rigor, Relevance, and Results: The Quality of Teacher Assignments and Student Work in New and Conventional High Schools. Washington, DC: American Institutes for Research and SRI International.

Mokhtar, F., and Gross, S. (2020). Should Schools Close to Fight Virus? These Places Say no. Bloomberg. Available online at: https://www.bloomberg.com/news/ articles/2020-03-27/should-schools-close-to-fight-virus-these-countries-sayno (accessed October 1, 2020).

Narvaez Brelsford, S., Camarillo, E. E., Santana Garcia, A., Garcia, G., Reyes Lopez, V., Paredez Montoya, C., et al. (2020). Keeping the bus moving while maintaining social distance in a COVID-19 world. Int. Stud. Educ. Admin. $48,12-20$.

Ovando, M., and Cavazos, M. (2004). Principals' instructional leadership in successful Hispanic majority high schools. Scholar Practitioner Q. 2, 7-24.

Ravani, S. (2020). Bay Area Coronavirus Decision: Behind the Scenes of Nation's First Shelter-in-Place Order. San Francisco Chronicle. Available online at: https://www.sfchronicle.com/bayarea/article/Bay-Area-coronavirusdecision-Behind-the-scenes-15148425.php. (accessed October 1, 2020).

Ravitz, J. (2010). Beyond changing culture in small high schools: Reform models and changing instruction with project-based learning. Peabody J. Educ. 85, 290-312. doi: 10.1080/0161956X.2010.491432

Reardon, R. M. (2011). Elementary school principals' learning-centered leadership and educational outcomes: implications for principals' professional development. Leadersh. Policy Schools 10, 63-83. doi: 10.1080/15700760903511798

Reimers, F. M., and Schleicher, A. (2020). A Framework to Guide and Education Response to the COVID-19 Pandemic of 2020. OECD. Available online at: https://read.oecd-ilibrary.org/view/?ref=126_126988-t63lxosohs\&title=Aframework-to-guide-an-education-response-to-the-Covid-19-Pandemic-of2020. (accessed October 1, 2020).

United Nations Educational, Scientific, and Cultural Organization (UNESCO) (2020). COVID-19 Impact on Education. Available online at: https://en.unesco. org/covid19/educationresponse. (accessed October 1, 2020). 
Zaldivar, J. I. (2011). Revisiting the critiques of Ivan Illich's deschooling society. Int. J. Cross-Discipl. Subj. Educ. 1, 618-626. doi: 10.20533/ijcdse.2042.6364.2011.0087

Conflict of Interest: The authors declare that the research was conducted in the absence of any commercial or financial relationships that could be construed as a potential conflict of interest.
Copyright $\odot 2021$ Rincones, Peña and Canaba. This is an open-access article distributed under the terms of the Creative Commons Attribution License (CC BY).

The use, distribution or reproduction in other forums is permitted, provided the original author(s) and the copyright owner(s) are credited and that the original publication in this journal is cited, in accordance with accepted academic practice. No use, distribution or reproduction is permitted which does not comply with these terms. 